\title{
Voices from Odisha: A Symbolic Study of Surendra Mohanty's The Changeover
}

\author{
Aishwarya Mishra
}

Department of English Literature, Ravenshaw University, India

Received: 01 May 2021; Received in revised form: 06 Jun 2021; Accepted: 15 Jun 2021; Available online: 22 Jun 2021 (C)2021 The Author(s). Published by Infogain Publication. This is an open access article under the CC BY license (https://creativecommons.org/licenses/by/4.0/).

\begin{abstract}
Images and Symbols are of great significance to any piece of literary work. Through its overtones it implies much more in addition to literal or primary meaning. In the process of describing the abstract through concrete subjects, it provides fresh insights and artistic expressions that supplant bland writing. This article attempts to examine the substantive and stylistic concerns connected to Symbolism as rendered by the Odia writer, Surendra Mohanty in his novel Kalantara (The Changeover, translated by Gurudev Meher). The article shall demonstrate the deeper meanings beneath its literary function. The events that occur in the novel are significant in a manner of foreshadowing the ethereal. Moreover, it prognosticates the sordid lives of the people residing in the Muktapur village with cosmic cataclysm in the milieu.
\end{abstract}

Keywords—symbols, cosmic cataclysm, metamorphosis, cyclone, patri-centric.

\section{INTRODUCTION}

Surendra Mohanty is an influential writer in Odia literature. Many of his influential works in Odia have been translated into English. He is honored with the Central Sahitya Akademi Award for his magnum opus Nilashaila. His well-known works comprise Mahanagarira Ratri (The Night of the Metropolis), Maralara Mrutyu (The Death of a Swan), Andha Diganta (The Dark Horizon), and Mahanirvana (The Final Departure), Kalantara(The Changeover, translated by Gurude vMeher). His collection of short stories embrace Yadubamsa O Anyaanya Galpa (The Yadubamsa and other stories), Rajadhani $O$ Anyaanya Galpa (The Capital and other stories), Krushnachuda (The Gulmohur) and Ruti O Chandra (The Bread and The Moon).He has a simple, comprehensible and appealing style.He has carved a niche for himself as the supreme manor of the Odia novel. His psychologically limitless description of characters is conspicuously sarcastic. He unfolds a monumental exploration of the disparate themes of fondness and hatred, slapstick and setback, helplessness and longing that maturate within family and societal relationships. He writes about nature and common men using powerful imagery and layman terms as if the incident is occurring right in front of his eyes. He is adored by his readers for his perspicuous diction in his novels, plays, short stories, critical and humorous essays, biographical sketches, features and editorials.

The Changeover is in many ways a revolutionary work depicting the transition of life before, during and after the cyclonic Storm. It presents an exquisite rendition of Muktapur village located in the Nayagarh district of Odisha. The village is a microcosm of Indian ethos and values. It depicts the typical agrarian lifestyle of people fighting on petty matters. The lives of the people have grown increasingly diverse and fragmented. The characters are corrupt, multifaceted and gossip-mongers. The storm ravages Muktapur village arousing alarm and terror in the minds of the people. No character ever feels personally satisfied with other characters.

Surendra Mohanty is admired for his efficient use of symbols in most of his works. Symbolism is a rhetorical device that allows a writer to convey his message or theme. It broadens the reasoning faculty of a reader in 
understanding a text. It enables the writer to depict the beauty or struggles of life in a thoughtful and unique way. In his novel,The Changeover (the original Odia title of the novel is Kalantara), Surendra Mohanty deftly uses a cyclonic storm as a symbol. The storm rises, gathers, raves and subsides but it brings about a metamorphosis in the life of the people of villageMuktapur.

An eminent Odia critic, Jitendra Narayan Patnaik cites, "The novels of Surendra Mohanty which deal with social and psychological realities are based on the themes of encounter between tradition and modernity, erosion of values, feelings of restlessness, agony and suffering among the youth, and social tension due to generation gap"(Patnaik 71).

The beginning, middle and end of the storm symbolize the three feet of Vamana, the fifth incarnation of Lord Vishnu. The first foot of Vamana that covered the Earth symbolizes the earthly existence of man. The social, familial and self-centered existence of characters in The Changeover like Dolagobinda (Headman of Mohanty street), Chandramani (a gossipmonger), Nilambar (a government college teacher), Anam Das (the Malika man), Nishamani (a learned person), Ketaki (a miserable widow), Damodar and Yogi Mahapatra (tormentors of Ketaki) come under the wide expanse of the first foot. The follies and foibles of the characters explored at the beginning of the novel correspond to the onset of the storm. Surendra Mohanty writes:

Before the storm began, everybody had a special identity and character of their own. Everybody had an innate desire and ability to take a decision. In their movement, there were an excitement of homecoming, good prospects and delight (Mohanty 45).

The second foot of Vamana that covered the sky symbolizesa transcendental stage that the characters attain when their petty jealousies, egos, greed for land and material attachments have been ruthlessly trampled by the intensity of the middle stage of the storm. Characters like Nilambar, Gopinath, Dolagobinda, Kulamani, and Alekh, caught in the eye of the storm advance to greet Kalantara, a new lease of life. The characters attain a state of life beyond the mundane existence. It seems as if the author has created the storm to create a symbolic moment of illumination. He sums of his vision of life in the following words: 'Nothing to fear! Nothing to dread! It's merely the pangs of rebirth, heralding the nascence of a new age. The Changeover'(Mohanty 65).

The third foot of Vamana that covered the Underworld corresponds to the subconscious and unconscious self of the characters in the novel. This state foregrounds the subconscious guilt of the characters. They realize their pettiness and attain essential human dimensions. For example, Mali Mishra, a pillar of the society, regrets his inhuman treatment of widowed Ketaki. He realizes her constraints that forced her to give birth to her illegitimate child and then kill the infant. He accepts her as his daughter and does not hesitate to have a glass of water from her to satisfy his thirst.

Thus, the author uses the storm as a supernatural event and a symbolic representation toreveal his vision of life and its wide-ranging dimensions.

The stages of the storm have been described vividly. The beginning of the storm has been depicted in the following manner:

The grey, broken clouds were listlessly moving afloat in the vaulted sky ... sometimes from the east to the west, and at others, from the west to the east. Gusts of humid wind, sweeping through the bamboo grove, made the battered fronds of the palm trees twist and turn with the weight of the wind, and then suddenly fell silent (Mohanty 36).

The eye of the storm has been depicted in the following manner:

Piles of straw, being blown away by a blast of stormy wind from the thatched hut of Lord Kaleshwar Mahadev, began to circle, like the dangling matted-hairs of an inebriated Shiva, engaged in his divine dance of tandav. The current of the air, sands, trash and dry leaves, made the sky dark and gloomy. Branches and foliage, uprooted from the Jagulei banyan tree, flew suspended in the open air, carried away by violent gusts of unruly wind, like the great Bhimasena's invincible mace, ready to strike, in the battle of Kurukshetra (Mohanty 44).

The end of the storm depicts a solemn stillness:

The raging wind blowing from the easterly direction suddenly abated. The heavy drops of rain, pouring on the lush landscape, were gradually becoming a fine drizzle. Eventually, the noise lessened and the drops, falling from the wet leaves, faded into a musical chime. A gentle stillness prevailed over the place (Mohanty 54). 
Often, characters serve as symbols, of a particular virtue or vice, or of a political creed which in turn assists the reader in enhancing the insight into complex subjects.

Nilambar, the protagonist of the novel is a symbol of humanity. He reveals his middle class mindset during the typhoon. His companion Kulamani cautions him about the threat of the storm on his life. Kulamani is the symbol of Nilambar's conscience. When the intensity of the wind decreases, Nilambar fetches his belongings instead of running for any shelter to save his life. Seeing this, Kulamani rebukes and asks him to give up his middle class mentality. Resting on the ridgeline, he restates, 'We survived just fine, thank heavens! And you are bothered about the luggage, babu?' (Mohanty 47). For an indigent fellow like Kulamani, Life is more valuable than his possessions. One is idealistic, other is down to earth.

Anam Das, the vagabond Malika man warns the village men of the upcoming threats to the village but the residents ignore and mock him by parading him on a donkey's back. He is a free-spirited rambler who enjoys his lone existence wandering all the time. He is wrapped in a red-ochre cloak and carries an oil-painted Patitapabana flagstaff with him and time and again recapitulates the Malika. He is a silent observer of the cataclysmic storm. He keeps on reiterating the words, 'Be Watchful! Be Watchful!'(Mohanty 72).He is scorned and disparaged by people rhythmically squalling, 'Look, the deluge has come along, the deluge has come along'. When Kanti was dying out of labourpain, everyone traced the whereabouts of Anam Das, promptly stating that he has got a cure to her excruciating pain. In that disastrous weather-worn condition, Anam Das makes a sneering comment 'Infanticide before the deluge! And childbirth during the deluge!'(Mohanty 21). Defying the ghastly storm, he roars, 'All shall perish by blind infatuation, why should Achuta cry? The informed shall merrily pass. The slothful shall die'(Mohanty 70).

The Patitapabana flagstaff is symbolic of advancement, innovation and discovery. It is a metaphor for knowledge. He predicts the future that other village people fail to do. Although everyone around mock and ostracize him, he comes at the rescue when Yogi Mahapatra insists him to extricate Kanti of her suffering. He represents mankind's power to alter and rejuvenate the world to best suit its needs. On another level, Anam Das's Patitapabana flagstaff can be compared to Piggy's eyeglasses in William Golding's The Lord of the Flies.

Piggy's glasses symbolize an interconnection to society and civilization and to scientific reasoning that generally erodes through the conflict in the novel. It is a representation of law and order to instil survival in an era of savage disorder. Likewise, Anam Das keeps on reciting the verses from Malika. It is a symbol of perception, and throughout the story it imparts reason and logic to a society that de-values knowledge and order. However, the derision of his lordship signifies the utter cessation of civility.

There is a graphic picture of animals and birds painted in the novel. These creatures can perceive what humans would consider to be nothingness. They possess awareness of predicting the onset of any havoc or natural disaster like earthquake, storm and volcano. Similarly, in the novel, a congregation of birds are seen flying to the eastern horizon of the arched sky. Jackals are suddenly spotted rushing southwards from the screwpine lane. Cows are seen noisily running eastward as if aware of some upcoming imperilment.A dog is seen whining since morning as if some deadening situation is about to happen. All these unusual behavior of animals are symbolic and presage some approaching danger. Shanian postulates, 'I have never seen a pack of jackals rushing like this. Signs like this, they say, portend danger ahead'(Mohanty 25).

Ketaki, the childless widow of Hara Sathpathy is the victim of patriarchal society and unequal power structure. Being flaccid and submissive, she was espoused to an old asthmatic man at the tender age of 15. A woman in a male-dominated society has to live a life of compromise, subservience and ignorance. In the malechauvinistic societies, women are incarcerated in the chains of culture. They experience social deprivation and political degeneration. There are a lot of obligations and double standards in the way their actions are looked upon. In the same way, Ketaki is refrained from expressing her opinions and desires. She is abstained from the protection of society and law. She is publicly questioned for her adultery and resulting infanticide. She becomes the victim of Sadism of her male compeers. The advocates and lawsuits exaggerate her case and frame the proceedings into their desired repercussions. The storm brings out her agony. She battles for survival against the greed of her kith and kin.Her brother-in-law expropriates her five acres of land and humiliates her before the society. Even her partner, Yogi Mahapatra has greed for her fields. Yogi posits, 'Is there anything more virtuous than the deliverance of an orphaned, helpless widow, and the disposal of her properties?' Behind this concern, his real motif is Ketaki's few acres of land.

An apparent comparison can be made between Ketaki and Thomas Hardy's Tess of the d'Ubervilles' heroine, Tess' condition. Despite their difference in the socio-cultural and geographical milieu, both the novels display portrayal of women in a patriarchal domain and their tempestuous relationship with the society they live in. 
Tess is merely an object of desire for her husband, Angel Clare. He compares her to the Greek Goddesses. For him, she is an embodiment of a 'pure woman' which she fails to live up with. He abandons her just after the marriage when she cannot conform to his standards of a perfect woman. By the same token, Ketaki is rumored and pushed to the limits. She endures the savage behavior of her male-folks. She retaliates in exasperation, 'Everyone is concerned with that few acres of land and properties. This is my home. My life. I'm the sole judge as to who stays here and who goes'(Mohanty 34).

Ketaki's Bhairavi Avatar is symbolic of all female being challenging the aura of a patri-centric society. When the westerly wind sweeps away houses, harvests, possessions and chattels, the villagers give up their shallow and unpleasant attitude towards Ketaki. Even the niggard, Mali Mishra who was previously exulted in the downfall of the vulnerable and helpless dead man's wife, transforms himself as a benevolent person during the storm. He bemoans, 'You must have been my begetting mother, in some previous lives, my daughter'(Mohanty 73).

All conflicts revolve around the Saraswati pavilion. The land is not litigated. It is surrounded by Gopinath Mohanty's arum farm on the side. In the back of the pavilion, there is bamboo thicket of Brahmin Street. Thus, the pavilion is the cynosure and the cause of disagreement between the two clans. At the time of Dussehra, it is a royal custom to observe Saraswati puja with the installation of clay image of Goddess Saraswati in the pavilion. This deed of Nishamani Mohanty was opposed by villagers as it is indicative of frivolity and slapstick. Each year, Lakshmi Maharana, the statue maker arrives at the village to prepare the clay image of Goddess Saraswati. But this year due to the tug of war between the two groups as to who is going to acquire the ownership of the land, the making of the statue progresses in a slow pace. The blind fold around the eyes of the Goddess remains intact. This blind fold symbolizes Queen Gandhari standing motionlessly amid the battle of Kurukshetra. After the passage of the westerly gale, the Saraswati pavilion becomes the shelter of all village folks. Everything except the Saraswati land is dismantled by the hurricane. Darkness swathes the pavilion. Due to the spark of lightening, the blind folded image appears ghostly. An eerie quietude encompasses the entire landscape.

The palm-leaf manuscripts of the Bhagavata Depository calligraphed by Nishamani Mohanty are illustrative of the dreams and aspirations of the ancestors of the Mohanty clan. The manuscripts represent the universally acclaimed heritage of the clan. The crashing of the walls of the depository and the mangling of the scripts indicate crumbling of the Mohanty clan as a whole and its disappearance into nothingness. Chandramani retorts regretfully, 'If they are allowed to be blown away by the wind, what should we be left with then?' (Mohanty 72).

The ending of the novel is symbolic of the changeover. In words of the writer new dawn begins and promises a new lease of life towards which all characters advance. This can be collated with the narrativeof the book of Genesis on the history of the first pact in the Bible. It explores the subject of a gigantic catastrophe and a new beginning, giving hope in the worst scenarios of our modern environmental situation. Change is so prevalent in the lives of the characters that it almost defeats description and analysis. One can think of it in a very general way as alteration. It is a consistent process, and rendered so by the existence of time.

This change is analogous to the Yuga cycle of World Ages. In this cycle, one ascends from a state of dearth, ignorance and unfulfillment to enlightenment and spiritual perfection. This doctrine depicts the passage from Kali Yuga, the age of doubt and darkness, when the human civilization degenerates leading to collapse of social structure, mindless hedonism, indisposition and maladies of both mind and body to Satya Yuga, the age of truth where everything is in a state of Utopia. As the name implies, beings of this age are truthful and free from all worldly desires. They lead a virtuous life being adhered to Dharma. As they rely on pure Prana, they possess miraculous propensity (siddhis), with which they can perform superhuman tasks. This change in the Yuga is unfolded in The Changeover through the tempest. The tempest manifests itself as an unusual force causing significant disruptions in the lives of the characters and ending with a great sense of resolution and hope. Change gradates over the universe, without exception.

At the metaphysical level, in the descending stage, every metamorphosis is marked by an extensive ignorance and depletion in mental abilities, whereas in the ascending stage, every alteration is accompanied by a sudden leap of consciousness, conspicuous by deeper knowledge and eternal sagacity. This change is made possible by the unleashing of the destructive hurricane resulting in replenishment of higher level of consciousness and aspirations.

\section{CONCLUSION}

Concluding, the cosmic cataclysm serves as the ultimate relief in a way of instilling awareness in the lives of the inhabitants. The social and psychological realities are grounded on tradition and modernity, degeneration of principles and ethics, agitation, suffering and social 
tension among the juvenile due to generation gap. The mysteries of creation and existence are unearthed through brutality of the cosmos. The populace encounter a concatenation of conflicts between the ethereal and sublunary. Each character embraces the transition from longing to fulfillment, desolation to fabrication, ambition to fruition. The raging tempest gusts through the lives and amplifies to something transcendental bringing about an aura of change and in the process metamorphosing the lives and restoring peace in the village. The first light of the day embellishes with benevolence and comradeship with others.

\section{REFERENCES}

[1] Golding, William. Lord of the Flies. Faber and Faber, September 1954.

[2] Hardy, Thomas. Tess of the d'Urbervilles: A Pure Woman.James R. Osgood, McIlvaine \& Co. 1891.

[3] Mohanty, Surendra.The Changeover. translated by Gurudev Meher, India: Bloomsbury,2019.

[4] Patnaik, Jitendra Narayan. 'Four Major Modern Odia Novelists'. Odisha Review, November 2008, pp 65-72. 